\section{Цитологічні особливості багаторазово метастазуючих тиреоїдних
папілярних карцином}

\section{Г.В. Зелінська}

ДУ «Інститут ендокринології та обміну речовин ім. В.П. Комісаренка НАМН України»

Резюме. Мета - комплексне цитологічне та імуноцитохімічне дослідження тиреоцитів пунктатів поопераційних реґіонарних метастазів папілярних тиреоїдних карцином із багаторазовим метастазуванням і порівняльний аналіз цитологічних характеристик первинних і повторних поопераційних метастазів у кожного пацієнта. Матеріал і методи. Цитоморфологічні та імуноцитохімічні дослідження з використанням моноклональних антитіл проти тиреоїдної пероксидази, тиреоглобуліну, антигену Кі-67 проводили на матеріалі тонкоголкових аспіраційних пункційних біопсій 26 метастазів, виявлених у поопераційний період (після проведення тиреоїдектомії та радіойодтерапії), отриманих від 12 хворих на папілярний тиреоїдний рак із багаторазовим метастазуванням. Результати. За результатами дослідження фенотипових характеристик тиреоцитів пунктатів метастазів рецидивуючих папілярних карцином щитоподібної залози з повторним метастазуванням виявлено зміни цитологічних та імуноцитохімічних характеристик тиреоцитів у пунктатах повторних метастазів порівняно з такими первинних метастазів. Показано вірогідне зниження експресії тиреоїдної пероксидази та тиреоглобуліну та появу фенотипової гетерогенності популяції тиреоцитів (світлі клітини, клітини з макулами, оксифільні клітини) повторних метастазів порівняно з первинними. Висновок. У клітинах метастазів рецидивуючих папілярних карцином із повторним метастазуванням виявлено втрату ознак диференціації - вірогідне зниження експресії тиреоїдної пероксидази та тиреоглобуліну та появу фенотипової гетерогенності популяції тиреоцитів.

Ключові слова: щитоподібна залоза, папілярна карцинома, тонкоголкова аспіраційна пункційна біопсія, рецидив, радіойод-рефрактерні метастази, тиреоїдна пероксидаза, тиреоглобулін.

Диференційований рак щитоподібної залози (ЩЗ) у більшості випадків має сприятливий прогноз і безрецидивний перебіг унаслідок проведення стандартної терапії (тиреоїд-

* Адреса для листування (Correspondence): ДУ «Інститут ендокринології та обміну речовин ім. В.П. Комісаренка НАМН України», вул. Вишгородська, 69, м. Київ, 04114 Україна. E-mail: zdovado@ukr.net

(с) Г.В. Зелінська ектомія, супресивна гормональна терапія та радіойодтерапія) та завдяки патогенетичним особливостям [1]. Але, за даними літератури, у 2-29\% випадків черездеякий час після тиреоїдектомії та радіойодтерапії відбувається повторне метастазування папілярного раку [2-4]. Таку вражаючу різницю між показниками 
частоти метастазування, наведеними різними дослідниками, пояснюють демографічними особливостями, різними гістологічними типами врахованих пухлин, різними хірургічними підходами тощо [2-4]. Виділяють три основних типи рецидивів папілярної карциноми Щ3: віддалені метастази, локальні рецидиви поза межами лімфатичних вузлів і метастази в лімфатичних вузлах [4]. Існують літературні дані щодо більшої частоти рецидивування таких гістологічних варіантів папілярних карцином ЩЗ, як висококлітинний, стовбчастоклітинний, онкоцитарний [5].

За даними клініки ДУ «Інститут ендокринології та обміну речовин ім. В.П. Комісаренка НАМН України», метастазування з утворенням регіонарних метастазів може бути навіть багаторазовим, із трансформацією, врештірешт, у радіойод-рефрактерні метастази, які втрачають здатність до накопичення радіойоду, що унеможливлює успішність радіойодтерапії. Оскільки багаторазове метастазування папілярного раку ЩЗ є незвичним явищем, актуальним є дослідження клініко-біологічних особливостей таких метастазів, а також фенотипових особливостей популяції їх тиреоцитів із метою виявлення цитологічних змін, які відбуваються в процесі онкогенезу папілярного раку Щ3. Тим більше, що літературних даних щодо досліджень цитологічних особливостей метастазів папілярного раку Щ3 із багаторазовим метастазуванням не знайдено.

Метою даного дослідження було проведення комплексних цитологічних й імуноцитохімічних досліджень тиреоцитів пунктатів регіонарних метастазів папілярних тиреоїдних карцином із багаторазовим метастазуванням і порівняльного аналізу цитологічних характеристик первинних і повторних поопераційних метастазів у кожного пацієнта.

\section{Матеріал і методи}

Дослідження проводили на матеріалі тонкоголкових аспіраційних пункційних біопсій (ТАПБ) 26 метастазів папілярних карцином (ПК), виявлених у поопераційний період, отриманих від 12 хворих на папілярний тиреоїдний рак із багаторазовим метастазуванням. Усім пацієнтам було проведено тиреїодектомію та радіойодтерапію. Цитологічні дослідження проводили на пунктатах, фіксованих метанолом і забарвлених за Романовським. Імуноцитохімічні дослідження проводили непрямим імунопероксидазним методом із використанням моноклональних антитіл миші проти тиреоглобуліну (DakoCytomation, Данія), тиреоїдної пероксидази (Dako, TPO-47), антигену Ki-67 (Clone MIB-1, DakoCytomation, Данія). У другому шарі використовували антитіла проти гамма-глобулінів миші, мічені пероксидазою хрону (DakoCytomation, Данія). Після проведення імуноцитохімічної реакції ядра клітин дофарбовували розчином гематоксиліну.

\section{Результати та їх обговорення}

В обстежених із гістологічним діагнозом «папілярна карцинома щитоподібної залози» після проведення тиреїодектомії та радіойодтерапії в поопераційний період з'явились регіонарні метастази. Перший метастаз (M1) було виявлено через 1-5 років після проведення тиреоїдектомії, а повторний (M2) - через 1-4 роки після виявлення та ліквідації першого метастазу. У 50\% випадків метастаз М1 був радіойод-чутливим, тобто накопичував радіойод. M1 інших хворих і всі М2 були радіойодрефрактерними, тобто накопичення в них радіойоду виявлено не було.

Цитологічні характеристики пунктатів метастазів M1 і M2 в пацієнтів із рецидивуючими ПК ЩЗ із повторним метастазуванням різнились. У пунктатах усіх метастазів М1 і в 10 з 12 метастазів М2 була присутня більшменш однорідна популяція одноманітних тиреоцитів: невеликого розміру (12-20 мкм), із помірним ядерно-цитоплазматичним співвідношенням, інколи з ознаками проліферації та деякого поліморфізму та без ознак вираженої атипії - ці клітини визначали як тиреоцити 1-го типу (рис. 1).

У пунктатах усіх метастазів М2 і в 1 випадку М1 були присутні тиреоцити 2-го типу, які складалися зі збільшених за розмірами (24-48 мкм) поліморфних базофільних клітин зі зменшеним ядерно-цитоплазматичним співвідношенням. Розташування тиреоцитів у пластах було нерегулярним, серед них траплялися світлі клітини, з вираженим світлозаломленням добре збереженої поверхні. Інколи 


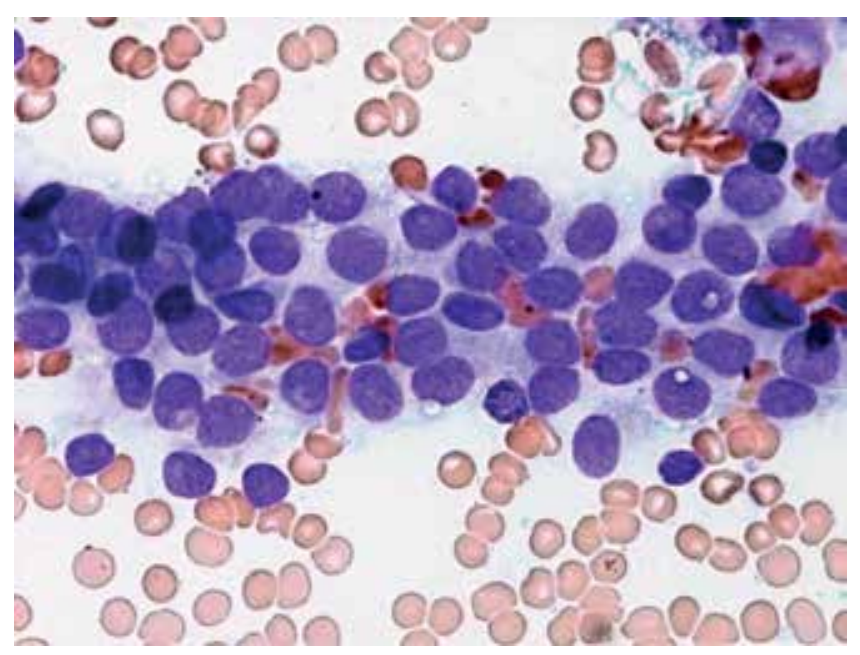

Рис. 1. Пунктат радіойод-чутливого метастазу М1 ПК ЩЗ: цитологічну картину представлено однорідною популяцією тиреоцитів 1-го типу. Забарвлення за Романовським, об. ×40.
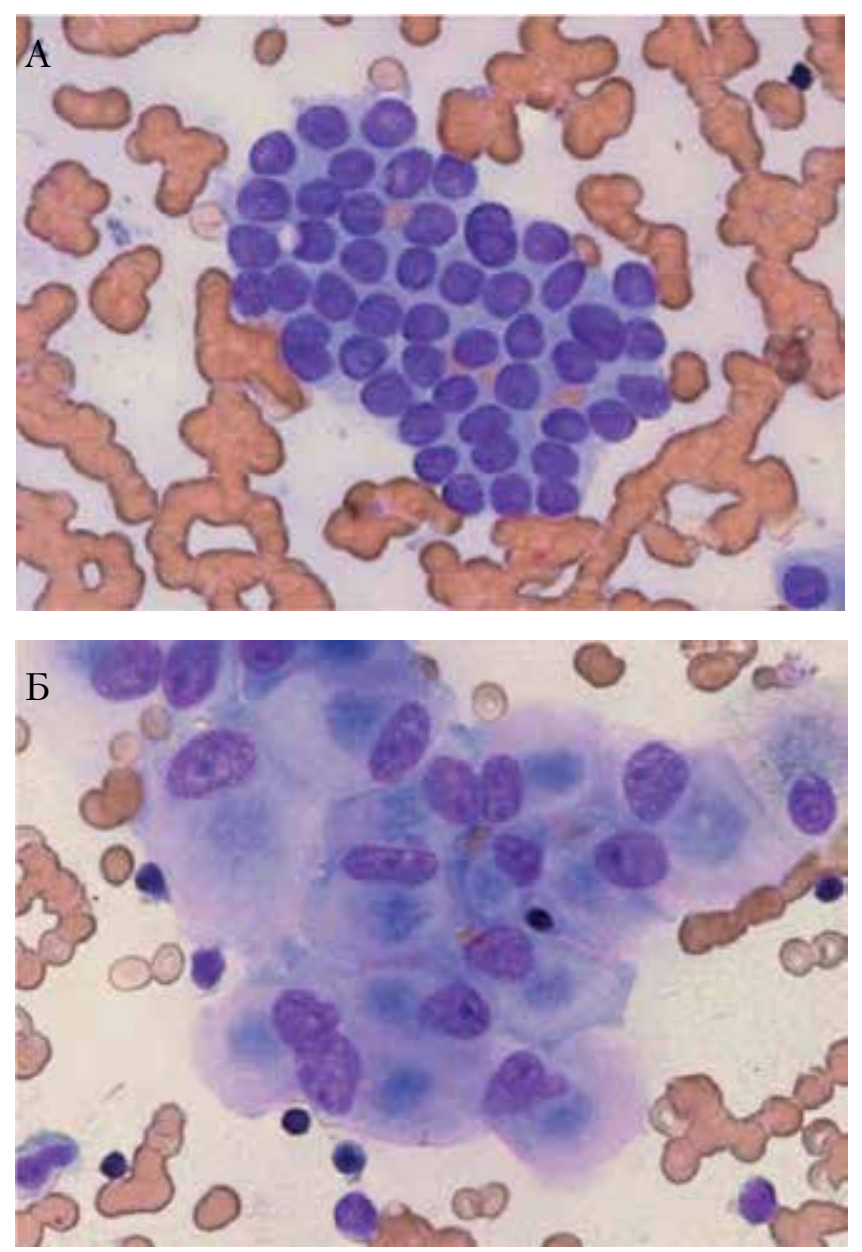

Pис. 3. Пунктати M1 (А) та M2 (Б): тиреоцити 1-го типу в пунктаті метастазу М1 і тиреоцити 2-го типу (із макулою) у $\mathrm{M} 2$ ПК Щ3.

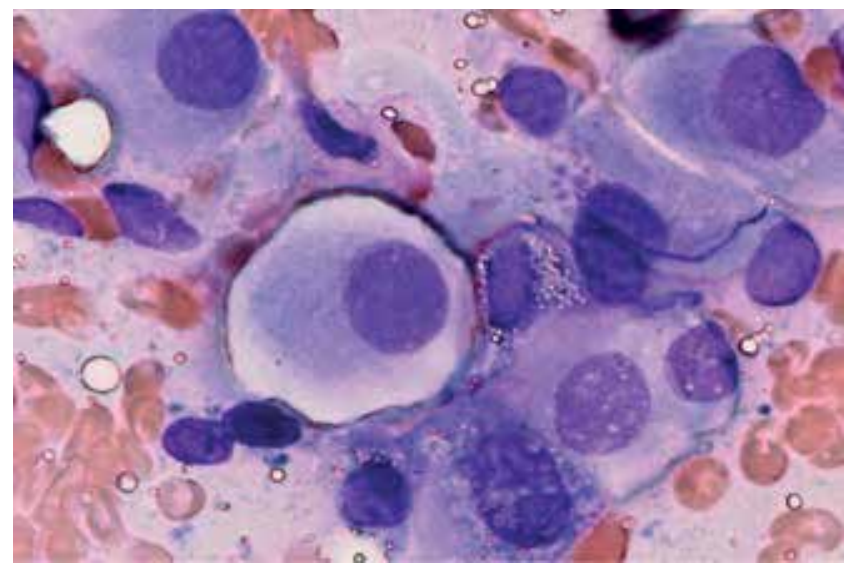

Рис. 2. Пунктат повторного радіойод-рефрактерного метастазу М2 ПК Щ3: тиреоцити 2-го типу, у тому числі світлі клітини. Забарвлення за Романовським, об. ×40.
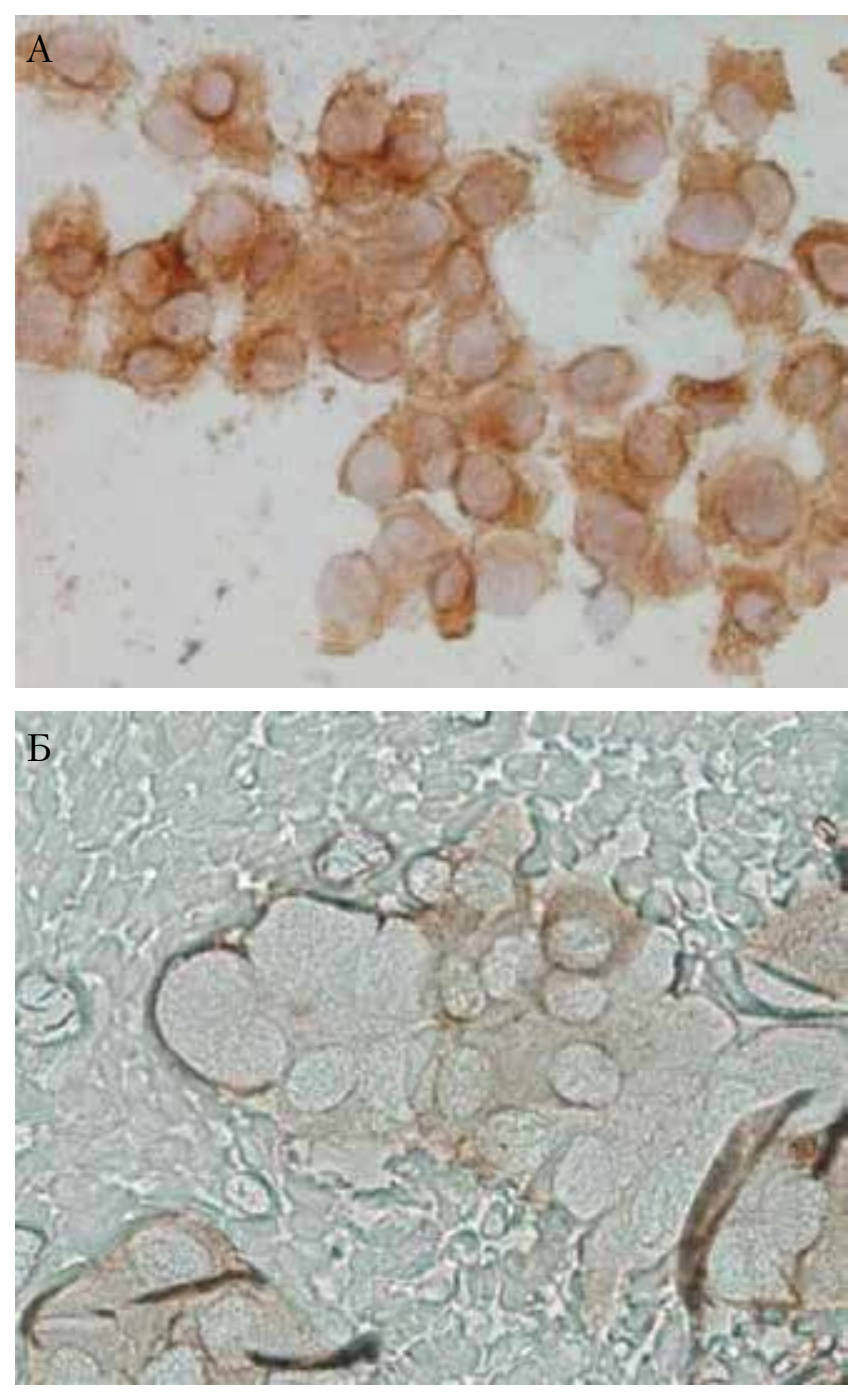

Рис. 4. Імуноцитохімічна реакція з антитілами

до тиреоглобуліну в тиреоцитах пунктату метастазів М1 (A) та M2 (Б) пацієнта з рецидивуючою ПК Щ3. О6. ×40, ок. ×3,3. 
можна було спостерігати клітини з базофільною «макулою», розташованою в цитоплазмі біля ядра (рис. 2).

Порівняння цитологічних характеристик пунктатів метастазів M1 і M2 засвідчило зміну однорідно-клітинної цитологічної картини, характерної для радіойод-чутливих метастазів (РЙЧМ), на поліморфно-клітинну з наявністю різних типів тиреоцитів і нерегулярних клітинних пластів на тлі кістозної дегенерації, що є характерним для радіойод-резистентних метастазів (РЙРМ) (рис. 3).

За наявністю тиреоцитів 1-го типу не виявлено значущої різниці між М1 і М2. Водночас за критерієм знаків знайдено вірогідну різницю між M1 і М2 за наявністю тиреоцитів 2 -го типу ( $\mathrm{p}=0,015861)$. Дійсно, якщо в пунктатах М1 виявляли лише тиреоцити 1-го типу (лише в 1 випадку знайдено тиреоцити 2-го типу), то в пунктатах М2, навпаки, тиреоцити 2-го типу виявлено в 11 з 12 випадків.

Слід відзначити різку зміну цитології пунктатів метастазів у 2 випадках, коли на відміну від однорідної цитологічної картини пунктату M1 цитологічну картину пунктату M2 було представлено різко атиповими тиреоцитами, які навіть нагадували клітини низькодиференційованої карциноми.

Імуноцитохімічне порівняльне дослідження експресії в пунктатах метастазів антигенів, причетних до акумуляції радіойоду тиреоцитами, - тиреоїдної пероксидази (ТПО) та тиреоглобуліну (ТГ) - показало, що імуноцитохімічні характеристики радіойод-чутливих метастазів М1 були подібними - більшість їх тиреоцитів містили ТПО та ТГ, експресія яких зникала або різко знижувалась у пунктатах радіойод-рефрактерних метастазів М2.

У випадках, коли метастази M1 і М2 були радіойод-рефрактерними, експресія ТПО була відсутня в обох метастазах або не перевищувала $16 \%$ у М1, а в М2 дорівнювала нулю. Якщо в групі метастазів М1 експресія ТПО не виявлялась у 41,7\% випадків, то в групі М2 вона була відсутня в 75\% випадків. Не було випадків М2, коли відсоток ТПО-позитивних тиреоцитів перевищував 50\%. Водночас у групі метастазів М1 такі випадки становили 6,7\%.

Експресія ТГ також різнилася в пунктатах метастазів M1 і M2. Якщо в групі M1 у 66,7\% випадків відсоток ТГ-позитивних клітин перевищував 50\%, то в групі метастазів М2 частота таких випадків становила лише 33,3\%. Отже, виявлено тенденцію до зниження експресії ТГ і ТПО в М2 порівняно з такою в M1 (рис. 4).

Для статистичного порівняння відсотків ТПО та ТГ-позитивних клітин між групами метастазів M1 і M2 використано критерій Вілкоксона для залежних вибірок. Виявлено статистично значущі відмінності між експресією ТПО в групах M1 і M2 (p=0,017961). Порівняння груп M1 і M2 за відсотком ТГ-позитивних клітин також виявило вірогідні відмінності між групами $(p=0,030985)$. Результати наведено в таблиці.

Оскільки ТПО та ТГ необхідні для захоплення йоду тиреоцитами, їх експресія може прогнозувати успіх лікування метастазу радіойодом [6]. Слід відзначити тенденцію до збільшення проліферативної активності клітин від М1 до М2. Якщо в групі М1 відсоток Кі-67-позитивних клітин становив $0-5 \%$, то в групі М2 він сягав 11\%. За даними літератури, високий вміст Кі-67-позитивних тиреоцитів у гістологічному матеріалі ПК Щ3 (>4\%) $€$ незалежним чинником прогнозу агресії пухлин та їх схильності до рецидивування [7].

Отже, за результатами дослідження фенотипових характеристик популяції тиреоцитів метастазів рецидивуючих ПК ЩЗ із повторним метастазуванням виявлено зміни цитологічних та імуноцитохімічних характеристик тиреоцитів у пунктатах повторних метастазів M2 порівняно з такими первинних метаста-

таблиця. Цитологічні та імуноцитохімічні характеристики реґіонарних метастазів рецидивуючих папілярних карцином щитоподібної залози з повторним метастазуванням після тиреоїдектомії та радіойодтерапії, n (\%)

\begin{tabular}{|c|c|c|c|c|c|c|c|c|c|}
\hline \multirow[t]{2}{*}{ M } & \multirow[t]{2}{*}{ РЙРМ } & \multirow[t]{2}{*}{ РЙЧМ } & \multicolumn{3}{|l|}{ Клітини } & \multicolumn{4}{|c|}{ Клітини, які містять } \\
\hline & & & 1-го типу & 2-го типу & Оксифільні & $\begin{array}{l}\text { ТПО } \\
0 \%\end{array}$ & $\begin{array}{l}\text { ТП० } \\
>50 \% \\
\end{array}$ & $\begin{array}{l}\mathrm{T \Gamma} \\
<50 \% \\
\end{array}$ & $\begin{array}{l}\mathrm{T \Gamma} \\
>50 \% \\
\end{array}$ \\
\hline$M 1, n=12$ & $6(50,0)$ & $6(50,0)$ & $12(100)$ & $1(8,3)$ & $2(16,7)$ & $5(41,7)$ & $2(6,7)$ & $4(33,3)$ & $8(66,7)$ \\
\hline$M 2, n=12$ & $12(100)$ & $0(0)$ & $10(83,3)$ & $12(100)$ & $2(16,7)$ & $9(75,0)$ & $0(0)$ & $8(66,7)$ & $4(33,3)$ \\
\hline
\end{tabular}

Примітка: $p=0,017961$ за відсотком ТПО-позитивних клітин між M2 і M1; $p=0,030985$ за відсотком ТГ-позитивних клітин між M2 і 11 (за критерієм Вілкоксона); $p=0,015861$ за наявністю тиреоцитів 2-го типу M2 і 1 1 (за критерієм знаків). 
зів М1. Так, у 50\% випадків клітини М1 були здатні до накопичення радіойоду, для них була характерною висока експресія ТПО і ТГ і ознаки клітин високого ступеня диференціювання. Натомість усі М2 втратили здатність до накопичення радіойоду та характеризувалися низькою експресією ТПО, а частіше її відсутністю (75\% випадків) і мозаїчною експресією ТГ ( $<50 \%$ ТГ-позитивних клітин у $66,7 \%$ випадів). Цитологічна картина повторних метастазів характеризувалася появою різко атипових клітин, світлих клітин, оксифільних клітин, що, імовірно, є проявом втрати високого ступеня диференціювання тиреоцитів та їх здатності до накопичення радіойоду.

Отримані дані збігаються з даними інших авторів, отриманими в порівняльних дослідженнях гістологічного матеріалу первинних карцином та їх РЙРМ. У 37\% випадків було відзначено зміни гістологічної структури від первинних пухлин до метастатичних радіойод-рефрактерних осередків тиреоїдних карцином, причому 70\% ПК прогресували в агресивніший гістотип, який було представлено в метастазах, із виявленням гістологічних ознак низькодиференційованої або висококлітинної карциноми. Втрату чутливості пухлини до радіойоду вважають наслідком зниження диференціювання ï клітин. Проявом цього явища є поява елементів низького ступеня диференціювання в метастатичних пухлинах таких пацієнтів [8].

Виявлену в даному дослідженні вірогідну різницю в цитологічних та імуноцитохімічних характеристиках тиреоцитів пунктатів метастазів M1 і M2 можна пояснити тим, що через генетичні зміни в популяції тиреоцитів метастазів М1 із часом з'являються клітинні субклони, можливо, поодинокі, серед яких є такі, що втрачають здатність до накопичення радіойоду, здатні до метастазування та утворення радіойод-рефрактерних метастазів М2 [9, 10].

\section{Висновок}

У клітинах метастазів рецидивуючих папілярних карцином із повторним метастазуванням виявлено втрату ознак диференціації вірогідне зниження експресії тиреоїдної пероксидази та тиреоглобуліну, та появу фенотипової гетерогенності популяції тиреоцитів.

\section{Список використаної літератури}

1. Haugen BR, Erik KA, Bible KC, et al. 2015 American Thyroid Association Management Guidelines for Adult Patients with Thyroid Nodules and Differentiated Thyroid Cancer. Thyroid. 2016;26(1):1-133.

2. Floros P, Hugely, Grigg R, et al. Recurrent Papillary Thyroid Carcinoma The Internet Journal of Otorhinolaryngology. 2010;13(1):1-5.

3. Ralph P, Tufano RP, Clayman G, Heller K. Management of Recurrent/ Persistent Nodal Disease in Patients with Differentiated Thyroid Cancer: A Critical Review of the Risks and Benefits of Surgical Intervention Versus Active Surveillance. Thyroid. 2015;1:15-27.

4. Clive Grant. Recurrence of papillary thyroid cancer after optimized surgery. Gland Surg. 2015;4(1):52-62.

5. Jian Zhu, Xinli Wang, Xiaoxuan Zhang, et al. Clinicopathological features of recurrent papillary thyroid cancer. Diagnostic Pathology. 2015;10(96). DOI: 10.1186/s13000-015-0346-5 PMID: 26168921 .

6. Dunn JT, Dunn AD. Update on intrathyroidal iodine metabolism. Thyroid. 2001;11(5):407-417.

7. Akira Miyauchi, Takumi Kudo, Mitsuyoshi Hirokawa et al. Ki-67 Labeling Index Is a Predictor of Postoperative Persistent Disease and Cancer Growth and a Prognostic Indicator in Papillary Thyroid Carcinoma. Eur Thyroid J.2013;1:57-64.

8. Ricorde-Filho JC, Ryder MD, Chitale A et al. Mutational Profile of Advanced Primary and Metastatic Radioactive Iodine-Refractory Thyroid Cancers Reveals Distinct Pathogenetic Roles for BRAF PIK3CA, and AKT1. Cancer Res. 2009;69(1):4885-93.

9. Pennec S, Konopka T, Gacquer D. Intratumor heterogeneity and clonal evolution in an aggressive papillary thyroid cancer and matched metastases. Endocr Relat Cancer .2015;22(2): P. 205-216.

10. Ling V, Chambers AF, Harris JF, et al. Dynamic heterogeneity and metastasis. J Cell Physiol Suppl. 1984;3:99-103.

(Надійшла до редакції 04.03.2019 р.)

\section{Цитологические особенности многократно метастазирующих тиреоидных папиллярных карцином}

\section{А.В. Зелинская \\ ГУ «Институт эндокринологии и обмена веществ им. В.П. Комиссаренко НАМН Украины»}

Резюме. Цель - комплексное цитологическое и иммуноци тохимическое исследование тиреоцитов пунктатов послеоперационных регионарных метастазов папиллярных тиреоидных карцином с многократным метастазированием и сравнительный анализ цитологических характеристик первичных и повторных послеоперационных метастазов у каждого пациента. Материал

и методы. Цитогические и иммуноцитохимические исследования с использованием моноклональных антител против тиреоидной пероксидазы, тиреоглобулина, антигена Кі-67 проводили на материале тонкоигольных аспирационных пункционных биопсий 26 метастазов, выявленных в послеоперационный период (после проведения тиреоидэктомии и радиойодтерапии), полученных от 12 пациентов с папиллярным тиреоидным раком с многократным метастазированием. Результаты. По результатам исследования фенотипических характеристик тиреоцитов пунктатов метастазов рецидивирующих папиллярных карцином щитовидной железы с повторным метастазированием выявлены изменения цитологиче- 
Оригінальні дослідження

ских и иммуноцитохимических характеристик тиреоцитов в пунктатах повторных метастазов по сравнению с первичными. Показано достоверное снижение экспрессии тиреоидной пероксидазы и тиреоглобулина и появление фенотипической гетерогенности популяции тиреоцитов (светлые клетки, тиреоциты с макулами, оксифильные клетки) повторных метастазов по сравнению с первичными. Выводы. В клетках метастазов рецидивирующих папиллярных карцином с повторным метастазированием выявлена утрата признаков дифференциации (достоверное снижение экспрессии тиреоидной пероксидазы и тиреоглобулина, появление фенотипической гетерогенности популяции тиреоцитов).

Ключевые слова: щитовидная железа, папиллярная карцинома, тонкоигольная аспирационная пункционная биопсия, рецидив, радиойод-рефрактерные метастазы, тиреоидная пероксидаза, тиреоглобулин.

\section{The cytological features of thyrocytes of reccurent thyroid papillary carcinomas with repeated metastasis}

\section{A.V. Zelinskaya}

SI «V.P. Komisarenko Institute of Endocrinology and Metabolism of Academy of Medical Sciences of Ukraine»

Abstract. Aim. Is cytomorphological and imunocytochemical studies of thyrocytes of punctates of metastases rec- curent papillary carcinomas with repeated metastasis and comparative analysis of cytological characteristics of therocytes of primary and repeated postoperative metastases of each patient. Material and methods. Cytomorphological and imunocytochemical studies using monoclonal antibodies against thyroid peroxidase, thyroglobulin and antigen Ki-67 were perfomed on the material of Fine Needle Aspiration Biopsy of 26 metastases of 12 reccurent papillary carcinomas with repeated metastasis. Results. It was shown a statistically significant reduction in the expression of thyroid peroxidase and thyroglobulin and the appearance of phenotypic heterogeneity in the thyroid population (light cells, macular cells, and oxyphilic cells) of repeated metastases compared to primary ones. The change in the phenotypic characteristics of metastases reflected the loss of cell differentiation from primary to secondary metastases and loss of radioiodine sensitivity. Conclusion. As a result of cytomorphological and immunocytochemical studies of punctures of recurrent papillary carcinoma metastases with repeated metastases, it has been shown that the phenotypic characteristics of the recurrent metastasis of these thyroid carcinomas show a tendency to loss of differentiation their cells (statistically significant decrease in the expression of thyroid peroxidase and thyroglobulin, and the appearance of phenotypic heterogeneity of thyrocytes' population).

Keywords: papillary thyroid carcinoma, fine needle aspiration biopsy, cytological diagnosis, recurrence of papillary cancer, radioiodine-refractory metastases, thyroid peroxidase, thyroglobulin. 